\title{
Effectiveness Of Tepid Sponge Compresses And Plaster Compresses On Child Typhoid Patients with Fevers
}

\section{Dwi Hastuti, Dewi Ummu Kulsum, Siti Rahmawati Ismuhu, and Oop Ropei}

STIKES Jenderal Achmad Yani, Indonesia

ORCID:

Dwi Hastuti: https://orcid.org/0000-0003-4982-4740

\section{Abstract}

Background: Typhoid is infectious disease which is still encountered widely in various developing countries, especially those located in the tropic and subtropics. Fever is a clinincal manifestation that is often the main complaint of the sufferer. Action can be done to lower body temperature that is tepid sponge compress and plaster compress. Purpose: The purpose of this study is to determine the comparison of the effectiviness of tepid sponge compress and plaster compress of changes body temperature in school age children with typhoid fever in cibabat hospital in year 2017. Methods: The method used is quasy experiment research method with the approach of pretest and post test two design group. As many as 24 samples were taken at the patient ward of hospital Cibabat. Respondents divided into two groups namely tepid sponge compress and plaster compress by way concecutive sampling. This study was conducted for 20 minutes at each intervenstion. Data analysis used Wilcoxon test, dependen $t$ test, and Mann-Withney. Results: Average body temperature before and after given tepid sponge compress are $38,75^{\circ} \mathrm{C}$ and $38,08^{\circ} \mathrm{C}$ with temperature different is $0,67^{\circ} \mathrm{C}$. While average body temperature before and after given palster compress are $38,80^{\circ} \mathrm{C}$ and $38,57^{\circ} \mathrm{C}$ with temperature different is $0,23^{\circ} \mathrm{C}$. Mann-Withney test result show that the $p$ value $=0,000<\alpha=0,05$ which means bottom tepid sponge compress is more effective in lowering body temperature in scholl age children compared with plaster compress. Conclusion: Based on the result of the study, it can recommend tepid sponge compress in the implementation of nursing care to lower body temperature in typhoid fever patients.

Keywords: Fever, Plaster compress, Tepid sponge

\section{Introduction}

Typhoid fever is a systemic infectious disease caused by Salmonella thypi. According to WHO (2014) cases of fever worldwide reached 16-33 million with 500-600 thousand deaths each year. Cimahi City Health Profile Report in 2014, the number of typhoid cases described in hospitals with an age range of 0-1 years was 283 cases, ages 1-4 
years were 778 cases, aged 5-14 years were 974 cases, and ages 15-44 2,256 cases in the year.

Symptoms of typhoid fever occur when there is an increase in rectal temperature above $38^{\circ} \mathrm{C}$, causing children to be at risk of seizures, and cause complications. So it must be fast in handling. Actions that can be taken to reduce fever are tepid sponge compresses and compress plasters (Kolcaba, 2007 in Bartolomeus, Haryani, and Arif, 2012; Darwis, 2010 in Syltami, 2014). Compress measures that can be done are tepid sponge compresses and compress plasters (Darwis, 2010 in Syltami, 2014). According to Alves and Almeida (2008, in Hamid 2011) tepid sponge is an alternative warm compress technique that is effective in lowering body temperature. The tepid sponge technique is a combination of block and wipe techniques. This technique uses compress blocks not only in one place, but directly in several places that have large blood vessels, but it also provides wiped in several areas of the body. Giving compress blocks directly in various places will facilitate the delivery of signals to the hypothalamus with more vigorous. Giving wipes will also accelerate the dilation of peripheral blood vessels which facilitates heat transfer from the body around the environment so that it accelerates the decrease in body temperature (Alves and Almeida, 2008 in Hamid, 2011).

Acourding Research by Hamid (2011) Decreased body temperature in the tepid sponge group began to occur at the 6th minute and continued to decline sharply until the 90th minute reached $1^{\circ} \mathrm{C}$. Research conducted by Setiawati $(2008$, in Bartolomeus, Haryani and Arif, 2012) states that the average decrease in body temperature when getting tepid sponge therapy is $0.97^{\circ} \mathrm{C}$ within 60 minutes. Implementation of tepid sponge should prepare warm water when the child has a fever and water that spreads to various parts of the child's body can cause discomfort. There is another option for a new innovative compress system that is ready to use, considered practical, and sold freely in pharmacies to reduce heat when a child has a fever, a compress plaster. this compress plaster efficacious reduce body temperature when experiencing a fever. Only by attaching a compress plaster that is ready to goto the child's body, and monitor the child's body temperature regularly (Darwis and Hardiningsih, 2010). Making compress compresses using hydrogel on polyacrylate-base. This hydrogel has become the basic material for making compress plaster which is widely used in Indonesia. Research conducted by Syltami (2014) says that the average temperature change of a child's fever before and after being given a compress plaster each is $0.6^{\circ} \mathrm{C}$ within 20 minutes. This research is supported by research by Fatkularini, Mardi, and Solechan (2014) that the average decrease in body temperature after being given a compress plaster of $0.4^{\circ} \mathrm{C}$ for 30 minutes. 
Case study of typhoid fever cases that occur in children in the inpatient hospital 1 last month of 2017 as many as 16 children, fever that often occurs at a temperature of $38^{\circ} \mathrm{C}-40^{\circ} \mathrm{C}$. Actions that are often taken by nurses to observe vital signs, especially temperature, collaborative antipyretic administration aimed at reducing the process of prostaglandin release so as to reduce fever. Warm compresses that are usually done by room nurses only compress on the forehead and armpit area. In addition to giving warm compresses, there are parents of patients who use compress plaster to reduce fever on the grounds it is easier to do than compress using warm water. The purpose of this study was to determine the effectiveness of tepid sponge compresses and compress plasters against changes in body temperature in school-age children with typhoid fever in Cibabat Cibabat Hospital in 2017.

\section{Methods}

The design of this study was quasi-experimental with the design of pre and post test two design groups (using two treatment groups). The research design was quasiexperimental with pre and post test with two design groups. Both groups measured body temperature before and after the intervention. The first group received intervention by compressing tepid sponges and the second group received intervention with compress plaster.

The population in this study were children aged 6-12 years according to the inclusion criteria. Children with typhoid fever with body temperature above $38^{\circ} \mathrm{C}-39^{\circ} \mathrm{C}$. Sampling method with consecutive sampling technique. From the results of the sample calculation for each group 12 children. The total sample from both groups compress tepid sponge and compress tape as many as 24 children. Instruments used with observation sheets, water thermometers to measure water temperature when it will compress tepid sponges, digital thermometers to measure body temperature, and the Standard Operating Procedure (SOP). The SOP is used to compress the mirror according to Marni 2016, and the plaster is compressed according to PT. Hisamitsu. Pharma Indonesia, 2016; Syltami, 2014.

The measuring instrument uses data from variables that can be measured through observation. When there is a typhoid fever patient who complains of fever with a temperature above $38{ }^{\circ} \mathrm{C}-39{ }^{\circ} \mathrm{C}$ will be done the measurement of body temperature (pretest) to determine the child's body temperature by using a digital thermometer. Before the research process was conducted the researchers conducted an ethics test to the Health Research Ethics Commission Departement Of Nursing High School Health 
Science JenderalAchmadYani by number 001/KEPK/IV/2017.In addition to maintaining the safety of the researchers also conducted a presentation with the health team at RS Cibabat to get input and approval in intervening against respondent. After the researcher conducted informed concent to parents the researchers took measures to give tepid sponge compress or plaster compress to his child. The action of compressing tepid sponge and plaster compresses aims to reduce the temperature of children who have a fever with a temperature above $38{ }^{\circ} \mathrm{C}-39^{\circ} \mathrm{C}$. After the temperature measurement and the patient is said to have a fever with a temperature above $38^{\circ} \mathrm{C}-39^{\circ} \mathrm{C}$, the patient will be given an intervention with a tepid sponge compress from patients $1-12$ and administration of compress tape from patients 13-24. For patients who were given an intervention compress tepid sponge, the temperature of the water was prepared first before compressing that is $30-35^{\circ} \mathrm{C}$ which was measured using a water thermometer. While in patients who were given compressed plaster, the amount of compress tape was prepared according to the client's needs. After the patient was given intervention, either tepid sponge compress or compress plaster, the second temperature (posttest) was measured to determine the effectiveness of tepid sponge compresses and compress plaster.

After the pretest is performed by measuring the minimum body temperature above $38{ }^{\circ} \mathrm{C}-39{ }^{\circ} \mathrm{C}$. Twelve of the first patients were given tepid sponge compresses. This procedure used washcloth to wipe the face, neck, body, hands and feet, followed by the back (back, buttocks, hands, thighs and legs) for 20 minutes and twelve second patients given compress tape. This tape will be applied to the frontal, axillary, and inguinal areas for 20 minutes. At the time of posttest, measurements of body temperature in the axillary area were used with a digital thermometer. This was done to determine the effectiveness of each treatment and see a comparison between antarapre and post. temperature measurements were carried out, the results were immediately recorded on an observation sheet. After 30 minutes of intervention, the respondent was given antipyretics according to the dose.

Data were tested for normality by saphiro-wilk test. Tepid sponge compressed pretest group was 0.023 (data is not normal) and the results of the post-test of tepid sponge compress were 0.013 (data not normal). pre test and post test in tepid sponge group is still not normal, so for bivariate analysis using Wilcoxon test, the results of normality test data in compress test plaster group is 0.058 (normal data) and compress test plaster post test is 0.135 (normal data) so using dependent $t$ test, to find out whether there was a significant difference between tepid sponge compresses and compress plaster to decrease body temperature in typhoid fever patients using the Man Whitney test. 


\section{Result}

In the process of collecting samples in the tepid sponge compress group it took 11 days from May 8-18, 2017, while the sample collection process in the compress tape group took 12 days from May 20 to 312017.

Based on table 1. shows that the results of the analysis of the average body temperature before applying a sponge compress is $38.75^{\circ} \mathrm{C}$, with a standard deviation of 0.21 . after being given a compressed tepid sponge of $38.08{ }^{\circ} \mathrm{C}$, with a standard deviation of 0.19 . There are differences in body temperature before and after being given tepid sponge compresses ( $p$ value $=0.002<\alpha=0.05$ ).

Based on table 2. In the compressed plaster group it was seen that the average body temperature before being given compress plaster was $38.80^{\circ} \mathrm{C}$, with a standard deviation of 0.19 ; after being given a compressive plaster of $38.57^{\circ} \mathrm{C}$, with a standard deviation of 0.22 . There are differences in body temperature before and after being given a compress plaster ( $p$ value $=0.004<\alpha=0.05$ )

Based on table 3. the average decrease in body temperature in the tepid sponge compress group was $38.08{ }^{\circ} \mathrm{C}$ with a standard deviation of 0.19 , while the average decrease in body temperature in the compressed plaster group was $38.57^{\circ} \mathrm{C}$ with a standard deviation of 0.22 . There were significant differences in the average decrease in body temperature between tepid sponge compresses and compress plaster in children with typhoid fever $(p$ value $=0.004<\alpha=0.05$ )

TABLE 1: Comparison of Body Temperature Before and After Done Compressing Tepid Sponge ( $n=12$ )

\begin{tabular}{|l|c|c|c|c|}
$\begin{array}{l}\text { Compressing tepid } \\
\text { sponge }\end{array}$ & $\mathbf{n}$ & Mean & SD & p-value \\
\hline Pre test & 12 & 38,75 & 0,21 & 0,002 \\
\hline Post test & 12 & 38,08 & 0,19 & \\
\hline
\end{tabular}

TABLE 2: Comparison of Body Temperature Before and After Provision of Compress Plaster ( $n=12)$

\begin{tabular}{|l|c|c|c|c|}
\hline Plaster kompres & $\mathbf{n}$ & Mean & SD & p-value \\
\hline Pre test & 12 & 38,80 & 0,19 & 0,004 \\
\hline Post test & 12 & 38,57 & 0,22 & \\
\hline
\end{tabular}

\section{Discussion}

The results of the study on 12 children who experienced typhoid fever showed an average body temperature before being given a tepid sponge compress that was 38.75 
TABLE 3: Differences in the Effectiveness of Compressing Tepid Sponge and Compress Plaster ( $\mathrm{n}=12$ )

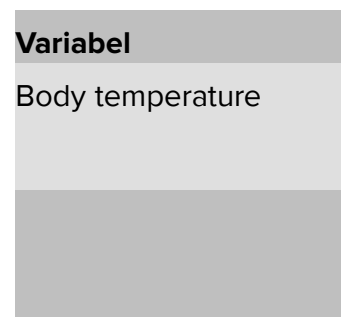

Kelompok
Post testtepid
sponge
compress
Post
testcompress
plaster

$\mathbf{n}$
12
12

\begin{tabular}{|l|}
\hline Mean \\
\hline 38,08 \\
\hline 38,57 \\
\hline
\end{tabular}

SD
0,19
0,22

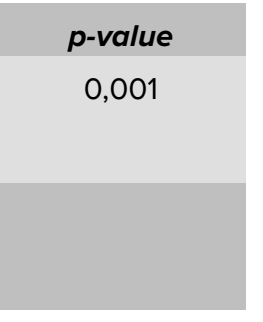

${ }^{\circ} \mathrm{C}$ after being given a sponge compress at $38.08^{\circ} \mathrm{C}$. All respondents who were given intervention in compressing the sponge experienced a decrease in temperature with an average value of $0.67^{\circ} \mathrm{C}$. Compress tepid sponges using washcloth to wipe the face, neck, body, hands and feet, continue with the back (back, buttocks, hands, thighs and legs) for 20 minutes. The advantages of tepid sponge technique by wiping the body of the patient is the wider body surface that is in contact with the compressing medium (washcloth) so that it will be very effective in reducing fever quickly. Due to other factors, one of which is room temperature, where the temperature shift between humans and the environment or room temperature occurs mostly through the skin (Tamsuri, 2012 in Mahdiyah, Rahman, and Lestari, 2015).

The results of this study used the Wilcoxon test and the results obtained $\mathrm{p}$ value $=$ 0.002 with $\alpha=0.05$ showed there was a difference in body temperature after being given tepid sponge compresses with a difference in the average decrease in body temperature of $0.67^{\circ} \mathrm{C}$. This is in line with the research conducted by Setiawati (2009) on "The effect of tepid sponge on decreasing body temperature and comfort in children who have a fever in the nursery of Muhammadiyah Bandung Hospital" which states that there are differences in temperature before and after the intervention of giving tepid sponge which was measured in the first 10 minutes after finishing the tepid sponge and the second measurement ( 30 minutes after the first measurement) with $p$ value $=0,000$ $<\alpha=0.05$.

Body temperature displacement according to Asmadi (2008) is classified into 4, namely radiation, conduction, convection, and evaporation. At compress the tepid sponge release of heat occurs through evaporation from the skin (Djuwariyah, 2011). Giving warm tepid sponge compresses to the body will give a signal to the hypothalamus through the spinal cord. When receptors that are sensitive to heat in the hypothalamus are stimulated, the effector system secretes signals that start sweating and peripheral vasodilation. Changes in the size of blood vessels are regulated by the vasomotor center of the medulla oblongata of the brain stem, under the influence of the anterior hypothalamic causing vasodilation. The occurrence of vasodilation will cause heat 
dissipation through increased skin (sweating), it is expected that there will be a decrease in body temperature so that it reaches a normal state again. If body temperature rises, the center of temperature regulation tries to reduce it, and vice versa (Nurwahyuni 2009, in Mohammad, 2011 in Mahdiyah, Rahman, and Lestari, 2015).

The results of the study on 12 children who experienced typhoid fever obtained an average body temperature before being given compress plaster was $38.80^{\circ} \mathrm{C}$ after being given a compress plaster was $38.57^{\circ} \mathrm{C}$. All respondents given the intervention of compress plaster experience a decrease in temperature with an average value of $0.23^{\circ} \mathrm{C}$. This is in accordance with Potter and Perry's theory (2010, in Syltami 2014) saying that fever occurs due to changes in setting points in the hypothalamus. or viruses that increase body temperature one of which is the bacterium Salmonella typhi. Nitrogen acts as an antigen that triggers the immune system response. The hypothalamus will increase the setting point and the body will produce heat. To reach the new setting point, it takes several hours. The results of the t-test depend on the results, $p$ value $=0.004<\alpha=0.05$, there is a difference in body temperature in children who have fever in typhoid fever patients after applying compress plaster with a flat difference the decrease in body temperature is $0.23^{\circ} \mathrm{C}$.

The results of this study are in line with research by Fatkularini, Mardi, and Solechan (2014) which states that there are differences in temperature before and after the intervention of giving compress plaster with $p$ value $=0,000<\alpha=0.05$. The implementation of fever using compress plaster is by how to attach plaster on the forehead, armpits and groin (Mardiyah, Rahman, and Lestari, 2015). In this study, compress plaster was applied to the forehead, armpit, and thigh folds with a frequency of 1 time for 20 minutes. Plaster compresses help the blood vessels in the skin to widen so that the pores become open which further facilitates the removal of heat from the body, so the body can experience a large drop in temperature (Djuwariyah, 2011 in Mardiyah, Rahman, and Lestari, 2015). The ready-made compress plaster is now widely circulated in the community with disposable packaging. This compress plaster is made from hydrogel on polyacrylate-base with the content of parabens and menthol formulated so as to accelerate the process of transferring heat from the body to compress plaster. Parabens are white crystals that dissolve easily in methanol, ethanol and are difficult to dissolve in water. The presence of a large water content in the hydrogel structure can be used to reduce fever through absorption of heat (energy) from parts of the body that fever and evaporate it (Darwis et al, 2010 in Mardiyah, Rahman, and Lestari, 2015).

The results of the analysis of the average decrease in body temperature after the tepid sponge compress was $38.08^{\circ} \mathrm{C}$ while the average decrease in body temperature 
after the application of compress plaster was $38.57^{\circ} \mathrm{C}$ obtained $\mathrm{p}$ value $=0.001<\alpha=$ 0.05 , there was a difference in the effectiveness of temperature reduction body on tepid sponge compresses and compress plaster. Effectiveness between tepid sponge compresses and compress plaster can be seen in the difference in the average decrease in body temperature, in groups using compressed sponges, the average temperature decreased by $0.67^{\circ} \mathrm{C}$, whereas in the plaster group compress is $0.23^{\circ} \mathrm{C}$. This proves that tepid sponge compresses are more effective in lowering body temperature in febrile patients diagnosed with typhoid fever. This difference is also caused by other factors, one of which is room temperature, where body temperature can experience exchange with the room or environment, meaning that body heat can be lost or reduced due to room temperature or cooler environment, and vice versa (Tamsuri, 2012 in Mardiyah, Rahman, and Lestari, 2015).

Providing complete compresses according to Kozier in Suprapti, 2008 in Syltami 2014, heat has a different effect on the body, the effect also depends on the duration of heat. Heat administration of 15-30 minutes has a vasodilating effect on blood vessels resulting in an increase in blood flow. Increased blood flow will reduce blood viscosity and local metabolism because blood flow carries oxygen to the tissues. Compress with temperature maintenance methods using liquids or tools that cause warm temperatures aims to facilitate blood circulation and provide a sense of comfort (Asmadi, 2008 in Fatkularini, Mardi, and Solechan, 2014).

The effectiveness of tepid sponge compresses in this study was supported by a previous study by Syltami (2014) on "Comparison of the effectiveness of tepid sponging and compress plaster in reducing body temperature in children under five who experienced a fever in PuskesmasSalaman 1" with $p$ value $=0,002<\alpha=0,05$, which means there is a difference in the decrease in body temperature in toddlers after doing tepid sponging and compress plaster. This is in line with the research that was also by Ernawati about "Comparison of plaster compresses with warm tepid sponge compresses to decrease in body temperature in Toddler children (1-3 years) who have a fever in Flamboyan $C$ RSUD KanudjosoDjatiwibowo Balikpapan "with $p$ value $=0,000<\alpha=0,05$, so it can be concluded that there are differences between the two groups after being given intervention compress plaster and compress warm tepid sponge.

\section{Conclusion}

The results of the study on the differences in the effectiveness of tepid sponge compresses and compress plaster on changes in body temperature in school-aged children 
with typhoid fever in Cibabat Hospital showed that there were differences in body temperature before and after applying tepid sponge compresses (Wilcoxonp test value $=0.002<\alpha=005$ ) and the difference in temperature decrease is $0.67^{\circ} \mathrm{C}$. There was a difference in body temperature before and after the application of compress plaster (dependent $\mathrm{t}$ test $\mathrm{p}$ value $=0.004<\alpha=0.05$ ) and a difference in temperature reduction of $0.23^{\circ} \mathrm{C}$. The provision of tepid sponge compresses was more effective in lowering body temperature compared to compressed plaster (Mann-withney test with $\mathrm{p}$ value $=$ $0.001<\alpha=0.05)$.

\section{Recomendation}

For hospitals, it is better to set a standard operating procedure for compressing the sponge to intervencie in nursing care for children who have a fever, especially typhoid fever because it has been shown to have an effect on reducing the child's body temperature. For nurses recommended tepid sponge compresses can be used as an implementation of self-care nursing to reduce body temperature in patients with typhoid fever.

\section{References}

[1] Alvin, R. (2013). Effectiveness of Warm and Normal Water Compress Giving in the Axillary and Frontal Areas in Children of Preschool Age Fever (3-6 years) in Humana Prima Hospital Inpatient Room 2013. (Stikes Jenderal Achmad Yani Cimahi, 2013).

[2] Bartolomeus, H. A. (2012). The Effect of Warm Tepid Sponge Compresses on Decreasing Body Temperature in Children 1-10 years old with Hyperthermia.

[3] Corwin, E. J. (2002). Pathophysiology Pocket Book. Jakarta: EGC.

[4] Dahlan, M. S. (2013). Sample Size and Method of Taking Samples. In Medical and Health Research (3 ${ }^{\text {rd }}$ ed.). Jakarta: Salemba Medika.

[5] Darwis, D. and Hardiningsih, L. (2010). Potential of Polyvinyl Pyrrolidone (PVP) Hydrogel-Gamma Irradiated Pigs as Fever-Lowering Plasters. Scientific Journal of Isotope and Radiation Applications, vol. 6, issue 1, p. 46.

[6] Darwish, et al. (2010). Development of Polyvinyl-Based Hydrogel (PVP) Electron Beam Irradiation as a Fever-Lowering Plaster. Vol. 11, issue 2, pp. 62-64.

[7] Djuwariyah, S. Y. (2013). Effectiveness of Decreasing Body Temperature Using Warm Water Compresses and Plaster Compresses in Children with Fever in the Kanthil room of Banyumas Regional Hospital Indonesia. 
[8] Ernawati. A (2017). Comparison of Compress Plaster with Tapid Sponge Warm Compress for Body Temperature Decrease in Toodle Children (1-3 Years) Experiencing Fever in Flamboyan Room C of Kanudjosowibowo Hospital, Balikpapan City. Vol. 1, issue 1, pp. 5-6.

[9] Electronic Reference Format Recommended by Jannah, Miptahul, 2015. Retrieved from Docslide.us/documents/water-tepid-spongedot.html.

[10] Electronic Reference Format Recommended by Nani, 2014. Retrieved from http://elibrarystikesnn.ac.id/files/disk1/3/e-library\{\%\}20stikes\{\%\}20hasanudin-saribungap_108-/article-8pdf

[11] Electronic Reference Format Recommended by PT. Hisamitsu Pharma Indonesia, 2016. Retrieved from www.hisamitsu.co.d / English / Products / byebye-Fever.

[12] Fatkularini, M. S. (2014). Effectiveness of Ordinary Temperature Compresses and Compress Plaster to Decrease Body Temperature in Children of Preschool Age Fever in Ungaran Hospital Semarang.

[13] Hamid, M. (2011). The Effectiveness of Tepid Sponge Compress Conducted by Thousand in Reducing Fever in Children: a Randomized Control Trial at the Mumbulsari Health Center in Jember district. (Thesis, Sebelas Maret University, Surakarta, 2011.)

[14] Hidayat, A.. A. (2009). Introduction to Child Health for Midwifery Education. Jakarta: Salemba Medika.

[15] Kozier, et al. (2010). Nursing Fundamentals, Concepts, Processes and Practices. Jakarta: EGC.

[16] Mahdiyah, Rahman, and Lestari. (2015). Differences in the Effectiveness of Warm Wet Compresses and Compress Plasters on the Decrease in Body Temperature of Typhoid Fever Children. Vol. 6, issue 1, pp. 35-45.

[17] Marni. (2016). Childcare in Tropical Diseases. Wonogiri Erlangga Publisher.

[18] Maryunani, A. (2010). Children's Health Sciences in Midwifery. Jakarta: TIM

[19] Mufaza, U. (2009). Knowledge and Behavior of Parents Against Antipyretic Giving to Children. (Thesis, Universitas Indonesia, 2009).

[20] Ngastiyah. (2005). Sick Child Care (2 ${ }^{\text {nd }}$ ed.). Jakarta: EGC.

[21] Nugroho. S. (2011). Treatment for Typhoid Fever. Yogyakarta: Nuha Medika.

[22] Nursalam, S. U. (2010). Baby and Child Nursing Care for Nurses and Midwives. Jakarta: Salemba Medika. 
[23] Ramadani, S. (2014). Comparison of the Effectiveness of Warm Compresses and Plaster Compresses in Lowering Body Temperature in Infants 1-10 Years Old Experiencing Fever in Bergas Health Center, Semarang Regency.

[24] Riyadi. S. (2009). Nursing Care in Children. Yogyakarta: Graha Science.

[25] Simanjuntak. (2009). Typhoid Epidemiology and Research Development. Mirror of the World of Medicine, issue 83 ,

[26] Setiawati, T. (2009). The Influence of Tepid Sponge on Decreasing Body Temperature and Comfort in Preschool and School Age Children Who Have Fever in the Children's Care Room of the Bandung Muhammadiyah Hospital. (Thesis, Jakarta, University of Indonesia, 2009).

[27] Setiawati, R. K. (2015). Effect of Tepid Sponge on Decreasing Body Temperature and Comfort in Children with Fever, vol. 2, issue 2, p. 4.

[28] Sodikin. (2012). Principles of Fever Care in Children. Yogyakarta: Learning Library.

[29] Suriadi, Y. (2010). Nursing Care for Children ( $2^{\text {nd }}$ ed.). Jakarta: Sagung Seto.

[30] Syaifuddin, (2006). Anatomy of Physiology for Nursing Students. Jakarta: EGC.

[31] Syltami, B. (2014). Comparison of the Effectiveness of Tepid Sponging and Compress Plaster in Reducing Body Temperature in Toddlers with Fever in Salaman 1 Health Center, Magelang Regency.

[32] Tamsuri. (2007). Vital Signs of Body Temperature. Jakarta: EGC.

[33] Widoyono. (2011). Tropical Disease Epidemiology, Transmission, Prevention \& Eradication (2 ${ }^{\text {nd }}$ ed.). Jakarta: Erlangga.

[34] Wilkinson, A (2011). Nursing Diganosis Pocket Book. Jakarta: EGC.

[35] Wong, et al. (2008). Pediatric Nursing Textbook (vol. 1). Jakarta: EGC. 